UDC 616.12-005.4:616.132.2]-089

\title{
Total arterial revascularization in patients with multi-vessel coronary artery disease: modern insight on conduit selection
}

\author{
Stukov Y. Y., Rudenko S. A., Rudenko A. V., Lazoryshynetz V. V. \\ National M. M. Amosov Institute of Cardiovascular Surgery of the National Academy Medical Sciences \\ of Ukraine (Kyiv)
}

\begin{abstract}
Coronary artery bypass grafting $(\mathrm{CABG})$ remains the most common operation performed by cardiac surgeons today. Fundamental basis of CABG is to reestablish perfusion to the myocardium, however there are different approaches in accomplishing this goal. The collection of scientific publications suggest the use of multiple arterial conduits in patients of young age, preferable without advanced comorbidity and low body surface area. Despite common use of saphenous vein grafts, lots publications demonstrate advantages of arterial conduits. Internal mammary artery (IMA) has patency rates in the region of $90-95 \%$ ten to fifteen years after CABG. Based on superior long-term results of the internal mammary artery (IMA), other arteries is being used in CABG. Radial artery (RA) nowadays it is the most popular arterial graft after the IMA in both low- and high-risk patients. Although, this conduit is underused, despite numerous observational studies, which documented excellent RA patency of $89 \%$ at 10 years. Furthermore RA and ITA grafting shows a strong protective effect against native coronary artery disease progression in symptomatic patients after CABG. The constellation of recent data and 2018 guidelines of European Society of Cardiology and European Association for Cardiothoracic Surgeons on myocardial revascularization suggest performing total arterial revascularization in patients with multi-vessel coronary artery disease.
\end{abstract}

Purpose. Literature review on recent data in surgical revascularization using multiple arterial grafts in patients with multi-vessel coronary artery disease.

Conclusions. Total arterial revascularization is safe and effective method in treatment of multi-vessel coronary artery disease. There is undoubted benefit of total arterial revascularization in short-, mid- and long-term results in frames of angina recurrence, major adverse cardiac events and redo surgery, associated with graft failure, compared to saphenous vein grafts. Total arterial revascularization may have protective effect on native coronary artery from disease progression, along with excellent patency rates in patients after CABG. However, clinical choice of grafts should be based on patient's general condition, coronary artery anatomy and severity of stenosis.

Key words: coronary artery bypass grafting, multi-vessel coronary disease, surgical revascularization, atherosclerosis, ischemic heart disease, coronary artery bypass grafting, radial artery, bilateral internal mammary artery, patency rates, total arterial revascularization

Over the past few decades, coronary artery disease (CAD) has become the leading cause of death in developing countries. Unpromising statistics of death rates from cardiovascular diseases in Ukraine (tab.1) illustrates the need for implementing effective primary prevention approaches, early recognition and effective treatment options. Coronary revascularization provides symptomatic relief from CAD and improves short and long-term outcomes. According to SYNTAX study, coronary artery bypass (CABG) grafting is superior to percutaneous coronary intervention (PCI) in patients with complex left main coronary artery (LMCA) or 3-vessel coronary artery disease (CAD). In the current article, we will discuss treatment options in terms of conduit selection and patency rates for total arterial revascularization (TAR) in patients with multi-vessel CAD.

The left internal mammary artery (LIMA) and saphenous vein grafts (SVG) remains the preferred mode of revascularization in patients with complex multi-vessel CAD. However, vein graft disease and early occlusion rates compared to arterial grafts give the cue to use multiple arterial grafts in patients with multi-vessel CAD. There is emerging evidence that use of bilateral internal mammary arteries (BIMA) significantly improve short and long-term outcomes, along with increasing benefits in terms of angina recurrence, major adverse cardiac events and redo surgery, associated with graft failure.

The first publication for the development of an extra coronary circulation with transplanting the internal mammary artery (IMA) performed Vasiliy Kolesov, by anastomosing the LIMA to the left anterior descending artery (LAD) in 1964, followed by Spencer the same year in the USA. Rene Favaloro made reports of BIMA use for CABG in 1968, but with the advent of SVG, the method of total arterial revascularization technique postponed to 1973, when Suzuki and associates published series of reports on direct anastomosis technique of the bilateral internal mammary arteries [1]. The first reports on successful clinical outcomes of BIMA grafting were published by the 
Tab.1.

Heart Disease and Stroke Statistics-2017 Update: A Report From the American Heart Association, . Death Rates for Cardiovascular Diseases and All Causes in Selected Countries Males and Females aged 35-74. Rates are per 100000 people. Sources: The World Health Organization, National Center for Health Statistics, and National Heart, Lung, and Blood Institute

\begin{tabular}{lcccc} 
Country & $\begin{array}{c}\text { Cardiovascular diseases male/ } \\
\text { female }\end{array}$ & $\begin{array}{c}\text { Corornary artery disease } \\
\text { male/female }\end{array}$ & $\begin{array}{c}\text { Stroke } \\
\text { male/female }\end{array}$ & $\begin{array}{c}\text { Total } \\
\text { male/female }\end{array}$ \\
\hline Ukraine & $1067.2 / 454.2$ & $718.1 / 294.7$ & $216.6 / 115.8$ & $2069.3 / 833.7$ \\
\hline Russian Federation & $1087.0 / 431.5$ & $610.2 / 212.5$ & $268.2 / 137.8$ & $2254.4 / 864.4$ \\
\hline Belarus & $1178.0 / 431.1$ & $826.0 / 271.3$ & $232.0 / 118.7$ & $2375.9 / 821.2$ \\
\hline France & $121.2 / 42.9$ & $46.4 / 10.0$ & $22.6 / 12.3$ & $718.4 / 330.7$ \\
\hline USA & $233.0 / 114.9$ & $125.3 / 48.5$ & $27.1 / 20.0$ & $810.7 / 514.0$
\end{tabular}

representatives of Cleveland Clinic, namely by B.W. Lytle and co-authors in 1983. Despite excellent results in patency rates, routine BIMA grafting restrain several factors: it is technically more challenging, more time consuming and is associated with increased risk of deep sternal wound infection (DSWI).

IMA has patency rates in the region of $90-95 \%$ ten to fifteen years after CABG [12]. Based on superior long-term results of the internal mammary artery (IMA), other arteries is being used in CABG. Such conduits include the radial artery (RA) and the gastroepiploic artery (GEA). Expectations on long-term results, compared to IMA, are based on the hypothesis that all arterial conduits have similar biological features, such as contractility, relaxing characteristics, endothelial function, and anatomic structure. Histologic studies have revealed that there are major differences among various grafts in terms of the structure of smooth muscle such as elastic lamellae [2]. The differences observed in these studies suggest that arterial grafts are not uniform in either anatomy or function. In contrast, comparative functional studies have demonstrated differences in arterial grafts with regard to contractility and endothelial function. These differences are the anatomic and physiologic bases of the divergent clinical manifestations of the grafts and may also account for the possible differences in postoperative graft function and long-term patency rates.

The unique feature of the IMA is its endothelium, which can produce significantly larger quantities of vasodilators such as nitric oxide and prostacyclin than venous grafts, resulting in greater endothelium-dependent relaxation (EDR) in response to acetylcholine, ADP, and thrombin in patients undergoing CABG [3]. The downstream flow of these endogenously secreted vasodilators into the coronary artery could also have a protective effect distal to the anastomosis, thus retarding the progression of CAD [4] by providing protection against atherosclerosis to the entire target vessel [5]. Even when BIMAs used in a Y-configuration, the endothelium-dependent and the endothelium-independent vasodilator capacity of the two limbs of the Y-graft IMA configuration appears to be similar 3 years after bypass surgery [6].
A comparative genome-wide transcriptional analysis of the LIMA, RIMA and the aortic wall revealed that the genes in the annotated atherosclerosis-signaling pathway are down regulated in both IMAs relative to the aorta [7]. Furthermore, signaling pathway genes for eicosanoids, which are signaling molecules associated with proinflammatory processes, are also expressed at lower levels in both IMA tissues. This transcriptional evidence, which reinforces the mechanism that BIMAs have an additional protective effect, is another argument in favor of BIMA use in CABG surgery [1].

The radial artery (RA) was first used by Carpentier and colleagues in 1974, but subsequently abandoned due to high failure rates, however, nowadays it is the most popular arterial graft after the IMA in both low- and high-risk patients. After early disappointing experiences of using RA graft for CABG, improved harvesting techniques, together with potential benefits of calcium channel blockers, have led to the RA becoming an increasingly popular conduit, as evidenced by improved patency and survival rates in observational cohort studies, when compared with SVG [8]. In framework of potential limb ischemic events, according to Gaudino, twenty-five patients underwent echo Doppler evaluation of the forearm circulation at a mean interval of $17.6 \pm 2.1$ years from surgery and in the operated forearm, there was a significant increase in the diameter of the ulnar artery $(2.44 \pm 0.43 \mathrm{~mm}$ vs. $2.01 \pm 0.47 \mathrm{~mm} ; \mathrm{p}<0.05)$. All other flow parameters were similar between the operated and control arms [9]. Although, this conduit is underused, despite numerous observational studies, which documented excellent RA patency of $89 \%$ at 10 years, and $86 \%$ at 20 years [10], which still constitute the first choice during the graft selection process.

According to Dimitrova and colleagues, RA and LITA grafting showed a strong protective effect against native coronary artery disease progression and excellent cumulative patency rates in symptomatic patients after CABG [11]. This benefit of arterial grafting may contribute to the better survival of the patients who underwent revascularization with more than one arterial graft. RA use resulted in a $75 \%$ decrease in disease progression in all coronary territories. 


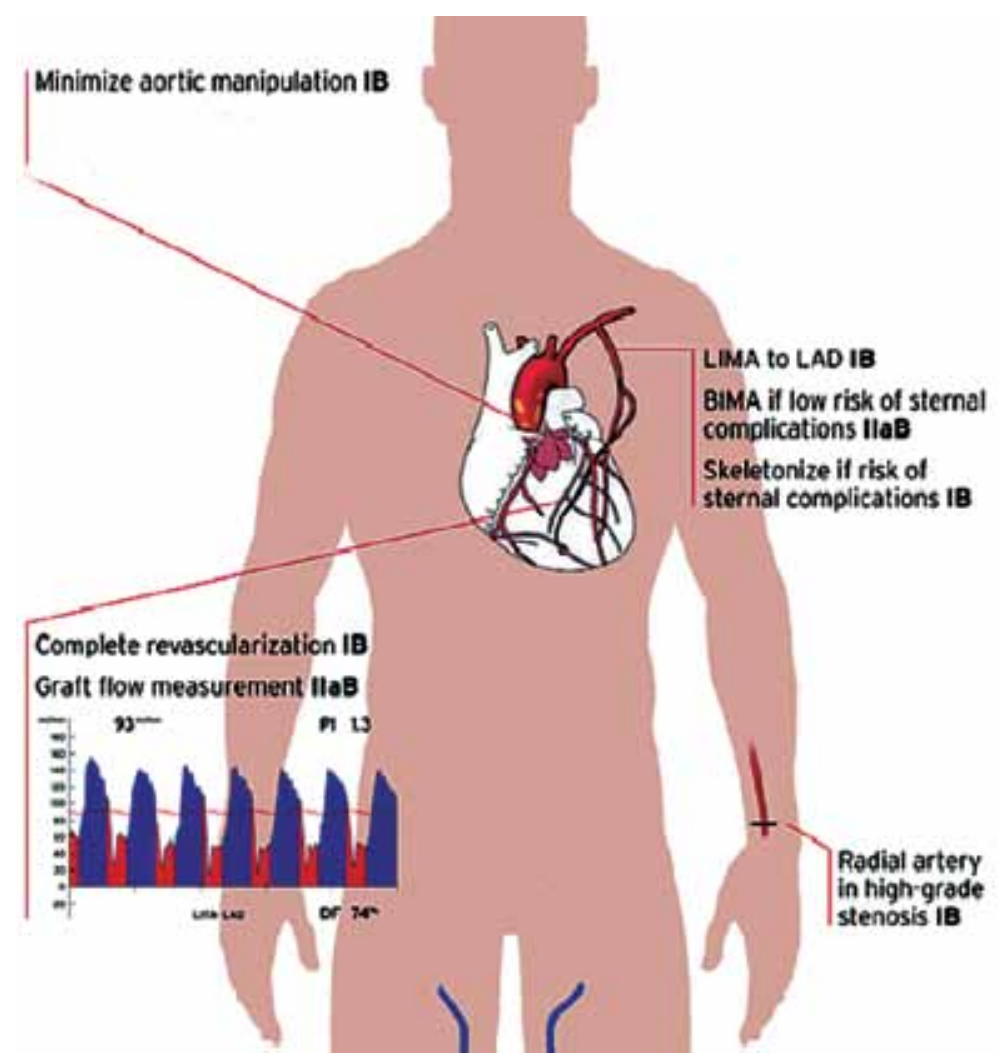

From 2018 ESC/EACTS Guidelines on myocardial revascularization
$[1,13]$. One of the commonest arguments against the utilization of BIMA is the higher risk of DSWI associated with it, which is apparently caused due to deprivation of blood supply to the sternum after BIMA harvest. Skeletonized BIMA harvest has been shown to reduce DSWI to as low as $1-2 \%$ from 10 to $11 \%$ observed with the pedicled technique in diabetic patients [1]. Increasing number of arterial grafts improves long-term survival and supports extended use of arterial grafts in coronary artery bypass graft surgery, irrespective of diabetes status [14]. Skeletonization results in better perioperative outcomes and comparable cardiac outcomes in patients undergoing BIMA with the greatest benefit in patients with chronic obstructive pulmonary disease [15]. Though, in the presence of concomitant risk factors for sternal wound infection such as DM and BSA $>35$, the RA should be considered instead of the right IMA to achieve multiple arterial grafting [16] in patients with LMCA and spared right coronary artery territory in frames of TAR. We suggest that COPD and obesity are the risk factors for sternal instability, dehiscence and infection. In our opinion diabetes is not the major risk factor for sternal dehiscence not only because of the use of skeletonized harvesting technique, but also because of routine use a reinforcement of both hemisternum with double longitudinal metal wire as described by Robicsek, in addition with careful management of postoperative glycemia.

Conclusions. Total arterial revascularization is safe and effective method of treatment multi-vessel coronary artery disease. There is undoubted benefit of total arterial revascularization in short-, mid- and long - term results in frames of angina recurrence, major adverse cardiac events and redo surgery, associated with graft failure, compared to saphenous vein grafts. Total arterial revascularization may have protective effect on native coronary artery from disease progression, along with excellent patency rates in patients after CABG. However, clinical choice of grafts should be based on patient's general condition, biological characteristics of the graft, coronary artery anatomy and severity of stenosis.

\section{References}

1. Piroze M. Davierwala, Friedrich W. Mohrab. Bilateral internal mammary artery grafting: Rationale and evidence // International Journal of Surgery. - April 2015. - Vol. 16, Part B. - P. 133-139.

2. Comparative anatomic studies of various arterial conduits for myocardial revascularization / Van Son JAM, Smedts F., Vincent J. G., Van Lier H. J., Kubat K. // J Thorac Cardiovasc Surg. - 1990. - Vol. 99. - P. 703-7.

3. Difference between endothelium-dependent relaxation in arterial and in venous coronary bypass grafts / T. F. Lbscher, was positively impacted by $\mathrm{BIMA}$ grafting $($ median
survival: $\mathrm{SIMA}=9.8$ years vs $\mathrm{BIMA}=13.1$ years; $\mathrm{p}<0.001)$ 
D. Diederich, R. Siebenmann, et al. // N. Engl. J. Med. 1988. - Vol. 319. - P. 462-467.

4. Why is the mammary artery so special and what protects it from atherosclerosis? / F. Otsuka, K. Yahagi, K. Sakakura et al. // Ann. Cardiothorac. Surg. - 2013. - Vol. 2. P. 519-526.

5. Evidence of nitric oxide produced by the internal mammary artery graft in venous drainage of the recipient coronary artery / F. I. Tarr, M. Sasvari, M. Tarr et al. // Ann. Thorac. Surg. - 2005. - Vol. 80. - P. 1728-1731.

6. Endothelium-dependent and endothelium-independent vasodilator response of left and right internal mammary and internal thoracic arteries used as a composite Y-graft / D. Glineur, S. Djaoudi, W. D'horre et al. // Eur. J. Cardiothorac. Surg. - 2011. - Vol. 40. - P. 389-393.

7. Comparative genome-wide transcriptional analysis of human left and right internal mammary arteries / G. Ferraria, J. Quackenbushc, J. Strobecka et al. // Genomics. 2014. - Vol. 104 (1). - P. 36-44.

8. Umberto Benedetto, Massimiliano Codispoti. Age cutoff for the loss of survival benefit from use of radial artery in coronary artery bypass grafting // The Journal of Thoracic and Cardiovascular Surgery. - November 2013. - Vol. 146, Issue 5. - P. 1078-1085.

9. Radial Artery as a Coronary Artery Bypass Conduit: 20-Year Results / Mario Gaudino, Paolo Tondi, Umberto Benedetto, Valentina Milazzo, Roberto Flore, Franco Glieca, Francesca Romana Ponziani, Nicola Luciani, Leonard N.Girardi,Filippo Crea, Massimo Massetti // Journal of the American College of Cardiology. - 9 August 2016. Vol. 68, Issue 6. - P. 603-610.

10. Tatoulis J., Schwann T. A. Long-term outcomes of radial artery grafting in patients undergoing coronary artery bypass surgery // Ann Cardiothorac Surg. - 2018. - Vol. 7 (5). - P. 636-643. doi: 10.21037/acs.2018.05.11

11. Arterial Grafts Protect the Native Coronary Vessels From Atherosclerotic Disease Progression / Kamellia R. Dimitrova, Darryl M. Hoffman, Charles M. Geller,Gabriela Dincheva, Wilson Ko, Robert F. Tranbaugh // Ann Thorac Surg. - 2012. - Vol. 94. - P. 475-81.
12. David P. Taggart. Current status of arterial grafts for coronary artery bypass grafting // Ann Cardiothorac Surg. 2013 Jul; Vol. 2 (4). - P. 427-430.

13. Bilateral internal mammary artery grafting enhances survival in diabetic patients: a 30-year follow-up of propensity score-matched cohorts / M. J. Dorman, P. A. Kurlansky, E. A. Traad et al. // Circulation. - 2012. - Vol. 126 (25). P. 2935-2942.

14. Incremental Value of Increasing Number of Arterial Grafts: The Effect of Diabetes Mellitus / Thomas A. Schwann, Abdul Karim M., E. Hage Sleiman, Maroun B. Yammine, Robert F. Tranbaugh, Milo Engoren, Mark R. Bonnell, Robert H. Habib // The Annals of Thoracic Surgery. June 2018. - Vol. 105, Issue 6. - P. 1737-1744.

15. The balance between short-term and long-term outcomes of bilateral internal thoracic artery skeletonization in coronary artery bypass surgery: a propensity-matched cohort study / Janet M C Ngu; Ming Hao Guo; David Glineur; Diem Tran; Fraser D Rubens // European Journal of Cardio-Thoracic Surgery. - 1 August 2018. - Vol. 54, Issue 2. - P. 260-266.

16. Searching for the second best graft for coronary artery bypass surgery: a network meta-analysis of randomized controlled trials / Umberto Benedetto, Shahzad G. Raja, Alberto Albanese, Mohammed Amrani, Giuseppe Biondi-Zoccai, Giacomo Frati // European Journal of Cardio-Thoracic Surgery. - 1 January 2015. - Vol. 47, Issue 1. - P. 59-65.

17. Franz-Josef Neumann, Miguel Sousa-Uva, Anders Ahlsson, Fernando Alfonso, Adrian P Banning, Umberto Benedetto, Robert A Byrne. Jean-Philippe Collet, Volkmar Falk, Stuart J Head, Peter Jьni, Adnan Kastrati, Akos Koller, Steen D Kristensen, Josef Niebauer, Dimitrios J Richter, Petar M Seferović, Dirk Sibbing, Giulio G Stefanini, Stephan Windecker, Rashmi Yadav, Michael O Zembala, ESC Scientific Document Group; 2018 ESC/ EACTS Guidelines on myocardial revascularization, August 2018.

Ethical approval: N/A for a review article.

Conflicts of interest: none declared.

\title{
Тотальна артеріальна реваскуляризація у пацієнтів з мультисудинним ураженням коронарних артерій: сучасний погляд на вибір шунта
}

\author{
Стуков Ю. Ю., Руденко С. А., Руденко А. В., Лазоришинець В. В.
}

ДУ «Національний інститут серцево-судинної хірургії імені М. М. Амосова НАМН України» (Київ)

\begin{abstract}
Аортокоронарне шунтування залишається найпоширенішою операцією, яку сьогодні виконують серцево-судинні хірурги. Фундаментальною основою аортокоронарного шунтування є відновлення перфузії міокарда, однак існують різні підходи для досягнення цієї мети. Сучасні наукові публікації рекомендують використання кількох артеріальних шунтів у пацієнтів молодого віку, без обтяжуючого анамнезу, супутньої соматичної патології та 3 невеликою масою тіла. Незважаючи на переважне використання аутовенозних шунтів, західноєвропейські колеги демонструють переваги тотальної артеріальної реваскуляризації. Внутрішня грудна артерія має показники прохідності в діапазоні 90-95\% від десяти до п’ятнадцяти років після операції шунтування. Виходячи з достовірних довгострокових результатів прохідності внутрішньої грудної артерії, було започатковано використання інших артеріальних шунтів. Променева артерія на сьогоднішній день $є$ найпопулярнішим артеріальним шунтом після внутрішньої грудної артерії у пацієнтів як із низьким, так і з високим рівнем ризику. Незважаючи на численні дослідження, променева артерія не використовується в повному обсязі операцій аортокоронарного шунтування,
\end{abstract}


незважаючи на відмінну прохідність променевої артерії на рівні близько $89 \%$ через 10 років після операції. Крім того, використання променевої артерії та внутрішньої грудної артерії демонструє значущий захисний ефект від прогресування атеросклерозу нативних коронарних артерій у симптоматичних пацієнтів після операції аортокоронарного шунтування. Збірники сучасних наукових публікацій та гайдлайни Європейського товариства кардіології та Європейської асоціації кардіоторакальних хірургів щодо реваскуляризації міокарда в 2018 році рекомендують тотальну артеріальну реваскуляризацію у пацієнтів із мультисудинним ураженням коронарних артерій, 3 класом доказовості IB.

Мета роботи - літературний огляд сучасних даних щодо хірургічної реваскуляризації з використанням кількох артеріальних шунтів у пацієнтів із мультисудинним ураженням коронарних артерій.

Висновки. Тотальна артеріальна реваскуляризація є безпечним і ефективним методом лікування при мультисудинному ураженні коронарних артерій. Беззаперечна перевага тотальної артеріальної реваскуляризації в ранньому, середньому і довгостроковому післяопераційному періоді знижує частоту виникнення рецидивів стенокардії, серйозних небажаних серцевих подій та ризики реоперацій, пов’язаних із дисфункцією шунтів, порівнян з аутовенозними трансплантатами. Тотальна артеріальна реваскуляризація може забезпечувати захисний вплив на нативні коронарні артерії від прогресування атеросклеротичного ураження, поряд із відмінними показниками прохідності у пацієнтів після операції аортокоронарного шунтування. Втім, вибір кондуїту має грунтуватися на загальному стані пацієнта, даних анамнезу, анатомії коронарних артерій та ступеня стенозу коронарних артерій.

Ключові слова: аортокоронарне шунтування, мультисудинне ураження коронарних артерій, ішемічна хвороба серия, хірургічна реваскуляризація, атеросклероз, променева артерія, бімамарне шунтування, тотальна артеріальна реваскуляризація. 